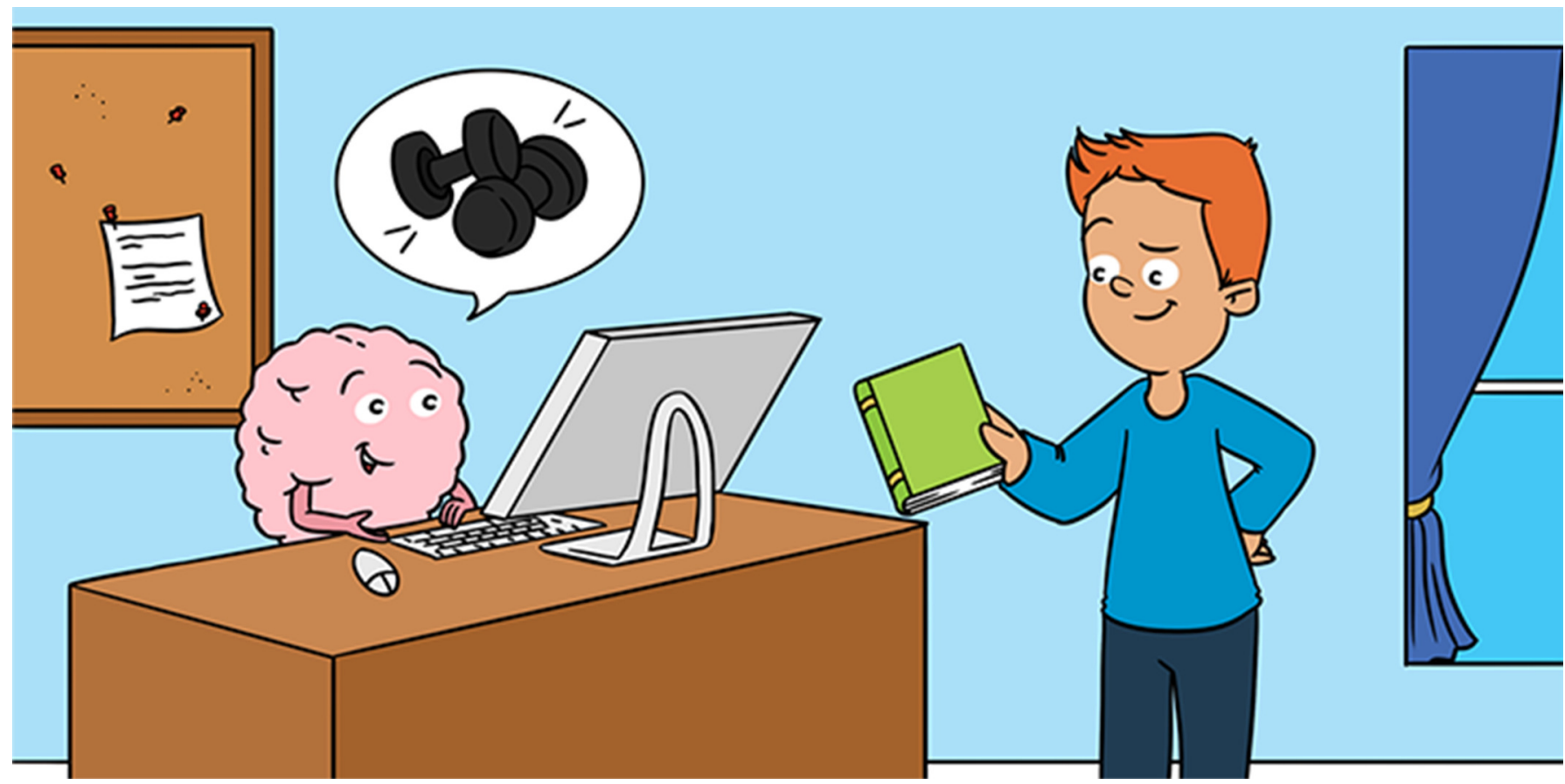

\title{
WANT TO TRAIN YOUR BRAIN? READ THIS ARTICLE!
}

\section{Dietsje Jolles ${ }^{1,2^{*}}$ and Linda Van Leijenhorst ${ }^{1,2}$}

${ }^{1}$ Institute of Education and Child Studies, Leiden University, Leiden, Netherlands

${ }^{2}$ Leiden Institute for Brain and Cognition, Leiden University, Leiden, Netherlands

YOUNG REVIEWER:

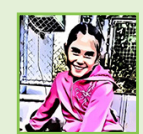

VELIANA

AGE: 11
Imagine that you could make yourself smarter simply by playing games. Wouldn't that be awesome? You spend a few hours at the computer every week, and you will be able to concentrate better, learn faster, and remember more. Your grades will skyrocket, you will finish school without any trouble, and life will be perfect. Wouldn't it? If you search the internet, it is not difficult to find games and apps claiming to boost your brain, allowing you to use its full potential. In this article, we will discuss the science behind these so-called brain-training games. We will argue that, in theory, it should be possible to make yourself smarter. However, the evidence that brain training will help you do so is mixed, at best. We will speculate about the next-generation brain-training programs and discuss alternatives for improving your thinking skills. Why not simply read a book?

Many kids dream of being smarter or more creative. If you search the internet, you will find games and programs claiming to help you with just that: boosting your brainpower. But is it really possible to make your brain work better? And are these so-called brain-training games 
Figure 1

Development is influenced by genes and the environment. (A) Imagine two boys, John and Ron. They are identical twins, which means that they have the exact same genes. For some reason, John and Ron grow up in different families. John's family members are all avid soccer players and like to go for runs on the weekends. Ron's family members love to stay inside to read and write stories. When John and Ron are twelve, they meet each other. (B,C) Although they are amazed by some of their similarities, they also notice that they have some significant differences. John is a sports enthusiast, who plays soccer and is the best runner in his class. Ron loves to read and write and takes great pride in getting good grades in school. Thus, although John and Ron have the same genes, their environments determined to what extent their talents were expressed.
A

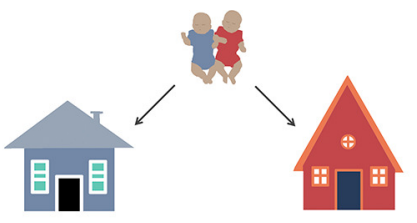

B

unning speed

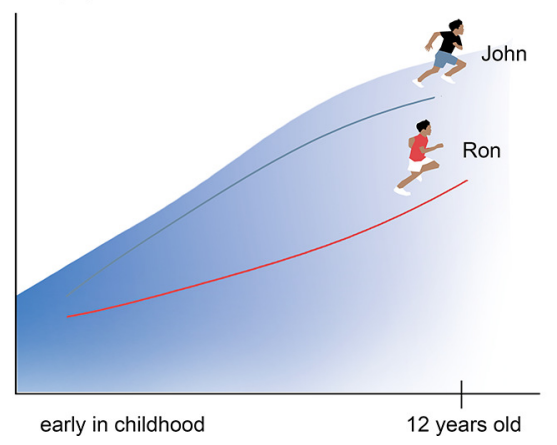

C

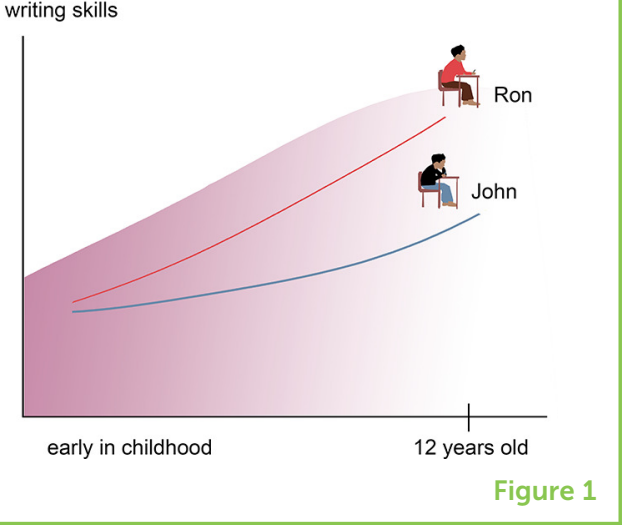

worth your valuable time? After reading this article, you can decide for yourself!

\section{YOUR FLEXIBLE BRAIN}

Have you ever thought about why some children excel in sports, whereas others are better at playing the guitar or performing mathematics calculations? Can you blame your genes for not being able to concentrate, or should you just try harder? For many years, scientists have tried to find out which parts of our talents and abilities are determined by our genes and which parts are influenced by the environment. It turns out that there is no simple answer to this question, because genes and the environment always work together [1]. Although your genes may influence the upper limits of your performance and your capacity to learn, your environment determines how your abilities actually develop. Thus, there is some built-in flexibility in the way your brain develops. This helps you to adjust to the environment that you grow up in. To explain this idea, we would like to introduce (fictional) John and Ron (Figure 1). John and Ron are identical twins, which means that they share $100 \%$ of their genes. Let us imagine that, for some reason, John and Ron are separated right after birth and raised in separate families. John grows up in a very athletic family, whereas Ron grows up in a family that is fond of reading and writing. It turns out that, although John and Ron have the same "runner" and "writer" genes, their different family environments influence the way their abilities develop. Whereas, John grows up to be an avid runner, Ron becomes a writer when he is older.

But what about being smart or talented in school? Research has shown that excelling in school has a lot to do with what are called executive 
EXECUTIVE

FUNCTIONS

Brain abilities that help you control your thoughts and behavior Executive functions are also called cognitive control by some researchers.

WORKING MEMORY

The ability to hold information in mind for a short time, so you can work with it.

\section{INHIBITION}

The ability to resist distractions and temptations.

COGNITIVE

FLEXIBILITY

The ability to switch back and forth between different tasks. functions [2]. Executive functions are a set of abilities that help you do complex tasks, such as planning your schoolwork, completing assignments, and having control over your emotions and frustrations. One of the most important executive functions is called working memory. Working memory allows you to hold information in mind and perform mental operations, for example, adding large numbers in your mind (Figure 2A). Another important executive function is inhibition, which helps you to resist distractions and temptations, for example, the temptation to eat the entire jar of cookies (Figure 2B). A third executive function is cognitive flexibility, which helps you to quickly shift your attention back and forth between different tasks, like switching back and forth between your homework and your YouTube feed (Figure 2C). To measure executive functions, researchers have designed a number of games that can be played on the computer (Figures 2D-F). It turns out that children who do better at these games also do better at school. Moreover, poorer executive functions have been associated with undesirable conditions, such as mental health problems, obesity, and social problems [2]. You might think that executive functions are hardwired in your brain, but that is not entirely true. Just like any other ability, executive functions are influenced by your genes and by your environment. That is good news, because it means that you have at least some control over the development of these functions. Childhood might even be the best time for boosting your brainpower. The same way that it is easier to shape a developing tree compared to a full-grown tree (Figure 3), it might be easier to train a developing brain than an adult brain [1,3]. Finally, it is important to note that although children's brains are more malleable than mature brains, children might not be as efficient and strategic when processing new information. This may hamper training effects a little bit.

\section{TRAINING YOUR BRAIN}

The internet is full of tips and tricks for optimizing your brain function, and numerous self-help books have been written about this topic. The advice includes getting enough sleep, eating healthy food, and exercising. But there is also something called brain training. According to the companies that offer such training, you can "train your brain in minutes a day," and users report impressive changes, ranging from improving their concentration to getting better at bowling [4]. Brain training usually refers to practicing the brain's executive functions. By performing complex mental tasks, your brain is working very hard, hence the name brain training. Moreover, research has shown that the brain changes with training [3], however, this is less impressive than it may seem. Everything you do makes small changes in your brain, whether it is walking your dog, meeting friends, or reading this article. Thus, brain training is a little bit of a misnomer. A more accurate name would be training of executive functions. 
Figure 2

Executive functions and associated brain-training games (A-C) Everyday activities that require executive functions: working memory, when you are adding large numbers in your mind; inhibition, when you are trying not to eat too many cookies; and cognitive flexibility, when you shift your attention between your homework and your YouTube feed. Games are often used to test and to train these executive functions. (D) In this working memory game, you have to hold several letters in mind and put them in alphabetical order. (E) In this inhibition game, you have to indicate the direction that the middle fish swims, and ignore the fish swimming in the opposite direction. (F) In this cognitive flexibility game, you go back and forth between a task where you have to indicate the shape of the big figure (rectangle), and another task where you have to indicate the shape of the small figures (squares).

\section{TRANSFER}

Using skills that you learned in one situation to improve your performance in a different situation.

\section{A Working memory}

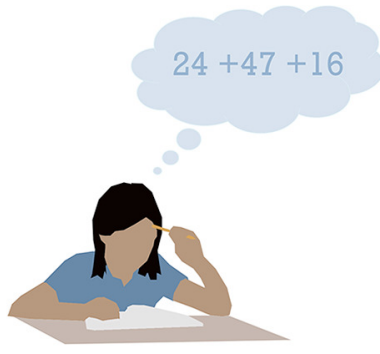

B Inhibition

C Cognitive flexibility

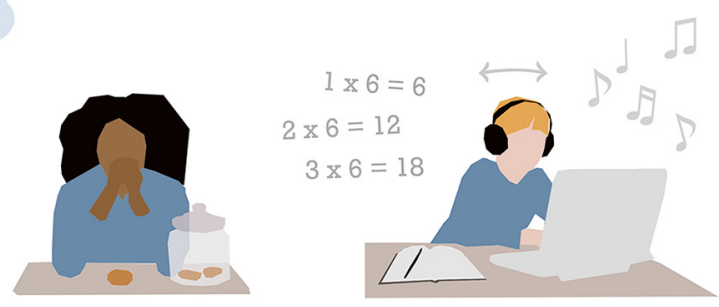

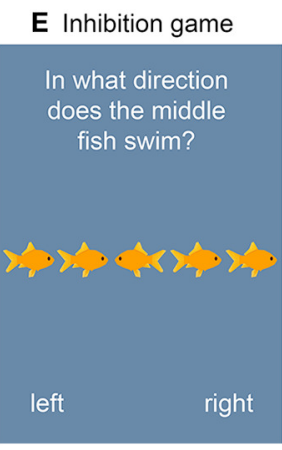

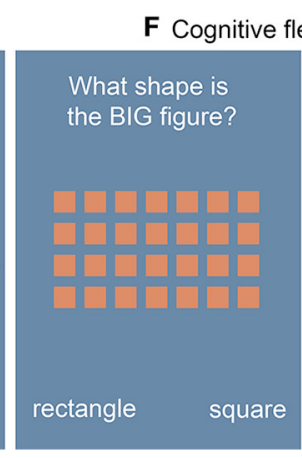

F Cognitive flexibility game

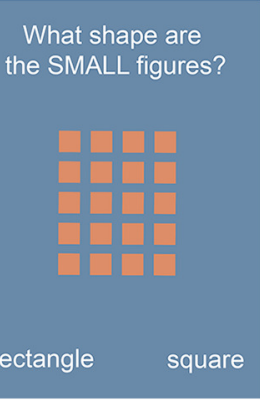

Figure 2
But does brain training work? Because executive functions are closely related to intelligence, school performance, and all sorts of other real-life outcomes, researchers have suggested that games that train the brain's executive functions might also lead to improvements in all these domains. In other words, because the everyday activities shown in Figures $2 \mathrm{~A}-\mathrm{C}$ require the same brain abilities as the games depicted in Figures $2 \mathrm{D}-\mathrm{F}$, you might improve in the everyday activities after training with the games. This is what researchers call transfer. Over the past 20 or so years, numerous scientific studies have been conducted to test whether transfer actually happens [4]. Results indicate that brain-training programs often improve performance on the tasks that are being trained. In other words, participants who practice reordering letters in working memory get better at reordering letters in working memory. There is also good evidence that participants get better at closely related tasks, for example, reordering digits in working memory. However, based on current evidence, we cannot yet conclude that brain training improves more distinct tasks, such as performance on math or reading assignments [4]. Thus, although you might improve tremendously on the games that you are using for training, this does not necessarily mean that you will notice any improvement in your daily life. It is often the case that the skills that you have learned apply only to the specific games that you were playing. To have more far-reaching effects, the next generation of brain-training programs might include a greater variety of activities, integrated into real-life situations. For example, activities to train your 


\section{Figure 3}

Pruning a developing tree is easier than pruning a full-grown tree. Researchers have argued that children have a greater capacity for learning and adapting to environmental circumstances than adults do, because children's brains are still in development. In other words, the same way that it is easier to prune a developing tree compared to a full-grown tree, it might be easier to train a developing brain than an adult brain.

\section{- \\ , \\ Pruning a developing tree}

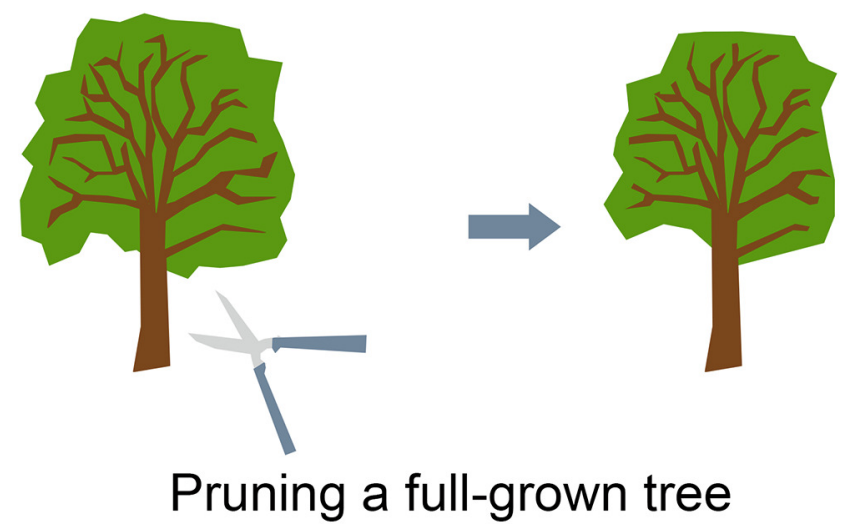

Figure 3

executive functions could be incorporated in complex video games or into school subjects.

\section{YOUR BRAIN ON BOOKS}

We know that the things you do every day help shape your brain, and we also know that it should be possible to train your brain. However, researchers are still trying to find the best ways to train the brain. Would you be willing to spend your valuable time on a brain-training program that might not have substantial effects? Or would you rather spend your time doing something fun, like playing sports or reading books? Interestingly, research has shown that physical activity is not only good for your body, but also for your brain. The effects of regular physical activity might even be more important for school performance than the effects of a brain-training program. Similarly, reading books appears to have more general effects on your thinking skills. Research suggests that regular reading helps make you smarter by building your vocabulary and increasing your background knowledge [5]. The cool thing is that, with every new memory you create, new connections are built in your brain and existing connections are strengthened. The more knowledge you have, the easier it becomes to learn even more [5]! 
Moreover, reading books might even train your thinking skills. Have you ever noticed how the rest of the world seems to disappear when you are absorbed in a story? This is possible because your brain is hard at work. When you read a book, you need to keep track of different characters, their backgrounds, goals, and details about their personalities and behavior. Moreover, you frequently need to read between the lines to understand what a book is about. To do these things, you use both your background knowledge and your executive functions. Without background knowledge you would not understand the words that are used, and without your executive functions you could never create a full story in your mind. Research has shown that children get better at these skills the more they read. Finally, besides increasing your memory and comprehension abilities, reading might help you to take the perspective of and sympathize with different characters, which is also an important skill for real life [6].

\section{CONCLUSION}

Even though your developing brain is super flexible, and it should be possible to make yourself smarter, the evidence that brain training will help you do so is mixed at best. Future brain-training programs will probably include multiple activities that are integrated into real-life situations. But do not wait for new programs! If you want to do something today to optimize your brain functions, stay active, eat healthy foods, get enough sleep, and keep on learning new things by doing lots of reading. Congratulations, you are doing it right now!

\section{ACKNOWLEDGMENTS}

This work was supported by the Jacobs Foundation (DJ). We would like to thank those who assisted in the translation of the articles in this Collection to make them more accessible to kids outside English-speaking countries, and for the Jacobs Foundation for providing the funds necessary to translate the articles. For this article, translation to Dutch was provided by the authors themselves.

\section{REFERENCES}

1. Stiles, J. 2008. The Fundamentals of Brain Development: Integrating Nature and Nurture. Cambridge, MA: Harvard University Press.

2. Diamond, A. 2013. Executive functions. Annu. Rev. Psychol. 64:135-68. doi: 10.1146/annurev-psych-113011-143750

3. Jolles, D., and Crone, E. A. 2012. Training the developing brain: a neurocognitive perspective. Front. Hum. Neurosci. (2012) 6:76. doi: 10.3389/fnhum.2012.00076

4. Simons, D. J., Boot, W. R., Charness, N., Gathercole, S. E., Chabris, C. F., Hambrick, D. Z., et al. 2016. Do "brain-training" programs work? Psychol. Sci. Public Interest 17:103-86. doi: 10.1177/1529100616661983 
5. Cain, K., and Oakhill, J. 2011. Matthew effects in young readers: reading comprehension and reading experience aid vocabulary development. J. Learn. Disabil. 44:431-43. doi: 10.1177/0022219411410042

6. Kidd, D. C., and Castano, E. 2013. Reading literacy fiction improves theory of mind. Science 342:377-80. doi: 10.1126/science.1239918

SUBMITTED: 14 October 2019; ACCEPTED: 01 May 2020; PUBLISHED ONLINE: 05 June 2020.

EDITED BY: Jessica Massonnie, University College London, United Kingdom

CITATION: Jolles D and Van Leijenhorst L (2020) Want to Train Your Brain? Read This Article!. Front. Young Minds 8:71. doi: 10.3389/frym.2020.00071

CONFLICT OF INTEREST: The authors declare that the research was conducted in the absence of any commercial or financial relationships that could be construed as a potential conflict of interest.

COPYRIGHT () 2020 Jolles and Van Leijenhorst. This is an open-access article distributed under the terms of the Creative Commons Attribution License (CC BY). The use, distribution or reproduction in other forums is permitted, provided the original author(s) and the copyright owner(s) are credited and that the original publication in this journal is cited, in accordance with accepted academic practice. No use, distribution or reproduction is permitted which does not comply with these terms.

\section{YOUNG REVIEWER}

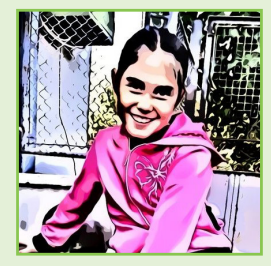

\section{VELIANA, AGE: 11}

I am Veliana and I am 11 years old. I love going to school. My favorite subjects are mathematics, English, and sports. In my free time I like playing sports, painting, and reading.

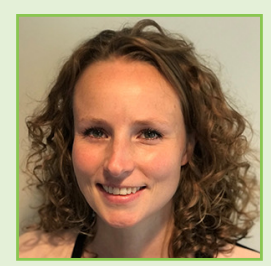

\section{AUTHORS}

\section{DIETSJE JOLLES}

During my early school years I always wanted to be a detective. Instead, I became a scientist. But being a scientist is a little bit like being a detective. My main subject: the miraculous workings of the developing brain. I am particularly interested in the way children, adolescents, and adults learn and how their learning is influenced by their brain development. I hope that my research will contribute to a better understanding of the brain and its development, and that it provides new insights that can help to improve education. *d.d.jolles@fsw.leidenuniv.nl

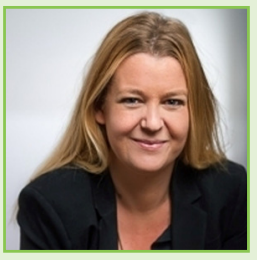

\section{LINDA VAN LEIJENHORST}

I am an assistant professor studying developmental cognitive neuroscience at Leiden University, The Netherlands. I am fascinated by the changes our brain goes through as we grow from child to adolescent to adult. I hope to some day understand 
how these changes influence the way we make sense of the world around us. Isn't it amazing that our brain allows us to experience the world, to dream and to imagine things? To learn more about this I study how children and adolescents make decisions and how they understand stories they read. 